\title{
On the Education Quality Construction of Independent College from the Perspective of Engineering
}

\author{
Li qinyi, Chen yiqing, Lv wuhua \\ Guang'an Vocational \& Technical College \\ Guangan Sichuan 638000 \\ 530062734@qq.com
}

\begin{abstract}
The quality of education is the lifeline and embodiment of the core competitiveness of higher education institutions. As a new derivative of Chinese higher education, the education quality of independent college not only affects the survival and development of independent colleges, but also the evaluation and recognition of independent colleges from the society. Therefore, the key for an independent college to survive or upgrade is education quality. This paper analyzes the development situation and problems existing in independent colleges in China from the perspective of engineering. Based on the $5 \mathrm{M1E}$ principle, this paper discusses the whole process of ensuring education quality and the control methods of education quality. At the same time, it puts forward some advice to improve the quality of education for independent colleges.
\end{abstract}

Keywords -Independent college; Quality of education; 5M1E; Quality control

\section{INTRODUCTION}

As a new school-running model of higher education, the independent college has been in existence for 19 years in the history of higher education in China. The independent college can be said to be a derivative of the popularization of higher education in China. At the end of the last century, in order to meet the needs of the country's economic development, the existing ordinary colleges and universities could not meet the needs of expanding enrollment. Each province, city and autonomous region has successively approved the independent college. Until 2003, the Ministry of Education issued the "Independent College Management Opinion", which established the basic concept of the independent college [1]. The university, which is produced through cooperation between enterprises and colleges and universities, solves the current desire to meet more undergraduate schools in the case of insufficient funding for college entrance examinations. In 2008, the Ministry of Education issued the "Establishment of Independent Colleges and Management Methods". In order to promote the rapid development of independent colleges, the state clearly pointed out the transition period to the independent colleges for five years, and strengthened the construction of software and hardware, and gradually departed from the alma mater to independence [2].

\section{ANALYSIS OF DEVELOPING SITUATION OF INDEPENDENT COLLEGE}

Up to May 2018, there are 265 independent colleges in China [3], and $21 \%$ of the national ordinary colleges and universities. Some independent colleges have been transferred to private colleges. For example, Polytechnic School of Shenyang Ligong University and Shenyang Agricultural University Science and Technology College jointly transferred to Shenyang Institute of Technology [4], Dalian Jiaotong University Information Engineering College was transferred to Dalian Institute of Science and Technology [5]. In 2008, the Ministry of Education's Decree No. 26 stipulates that there are three basic choices for the development of an independent college. One is to continue as an independent college; the other is transferred to a private higher institution that meets the requirements of the Ministry of Education; and the third is directly merged or revoked which are not in compliance with the requirements of the Ministry of Education. The five-year transition period for the independent college has long passed, and the number of independent colleges has decreased. Some outstanding independent colleges have been transferred or joined with other independent colleges to transfer into private colleges. After more than ten years of development, many independent colleges have achieved good results. The number of enrolled students has been increasing every year, and the scale of schooling has been expanding. But a good school is not only about the number of students in the school and the scale of schooling, but more importantly, the quality of education of this school. The quality of education is the foundation of the school. The quality of education of independent colleges plays a decisive role in the future development. The following is a detailed analysis of the quality of education in independent colleges. 


\section{ANALYSIS OF EDUCATION QUALITY OF INDEPENDENT COLLEGE}

Education quality and product quality are largely unified. There are two main factors to ensure the quality of a product: customer-centricity to meet customer' needs and volatility. The quality of education is no exception. Let's discuss these two factors separately.

\section{A. Customer-centric Concept}

The quality of education is a kind of product quality that is relatively special compared to the quality of ordinary products. The reason is that students can be regarded as products produced by schools or as customers. When students are regarded as products, the quality of products must meet the requirements of social diversification. The quality of products here also reflects the quality of education in schools. As a special product of the students, the consumers are the society or the employers. Whether the products produced by independent colleges can meet the needs of the society or employers is an urgent problem to be solved. As a product supplier of the society and employers across the country, choose the highest quality suppliers when they choose suppliers for the society and employers. When regarded students as customers, customers urgently need to meet their own high-level and highquality courses, need to get better education services, and need to meet the students' own development of teaching and training methods. As a customer, students have the right to get the rewards they have paid for, even if the independent colleges and the ordinary undergraduate schools do not receive government support in the education funds, relying on selffinancing and corporate funding to ensure the normal operation of the school, but there must be a basic guarantee for the quality of service for the customers you serve.

\section{B. Educational Quality Variability}

To ensure the stability of the quality of ordinary products, it is necessary to reduce the variability of the products. The quality of higher education is dynamic, first, the customer will have higher and higher quality requirements as the objective environment changes. Second, the higher education institutions as enterprises, and the standards of the courses and education services provided for the customers will also change with the progress of the times. The variability of common products can be analyzed by the $5 \mathrm{M} 1 \mathrm{E}$ principle, and the quality of education can also be analyzed by the $5 \mathrm{M} 1 \mathrm{E}$ principle.

\section{1) Man - teacher}

In the enterprise, the person who guarantees the product quality of the enterprise mainly refers to the employees and management of the enterprise. As a special "enterprise", colleges and universities ensure that the quality of their education is mainly the front-line teachers who are most closely connected with students. A well-structured and welltrained team of teachers is the foundation for ensuring the school's good functioning. A good faculty team ensures the sustainable development of the school. Take Polytechnic School of Shenyang Ligong University as an example to do a simple analysis. When the independent college was founded, most of its faculty members came to their alma mater's teachers, and the independent colleges had relatively few teachers. With the development of independent colleges, the number of teachers has gradually increased, but new problems have begun to appear. Although the number of teachers is increasing, the number of teachers who have increased has become polarized. Among them, young teachers have just graduated from other colleges and have no teaching experience; the other part is the retiring of old teachers after retirement. Due to the aged teachers, it will also have a certain impact on the quality of education. There is also a small part of the external employment. teachers. The irrational structure of the independent college teachers is a huge influence on the quality of independent college education.

\section{2) Machine - School Hardware}

High-quality products require not only high-quality employees, but also high-quality machinery. The machinery and equipment in the enterprise is equivalent to the hardware facilities of the school. Having a good teaching hardware is a prerequisite for ensuring the quality of education. Compared with ordinary colleges and universities, independent colleges are obviously behind in hardware facilities, mainly in school area, teaching area and teaching equipment. One of the seven independences prescribed by the Ministry of Education clearly stipulates that independent colleges must have independent teaching areas, independent colleges are limited by school funding, and independent colleges have a relatively small footprint. The construction area does not guarantee the normal use of students. The teaching equipment is very lacking compared with ordinary colleges and universities, and it is far from the national key universities. The main source of these is the lack of funding for running a school.

\section{3) Material - Student}

The "materials" of colleges or universities are students. When choosing a material supplier, enterprises can choose better quality. As a special company, an independent college has no right to choose a supplier. The independent college also implements the national unified enrollment system in the same way as the ordinary undergraduate colleges. The general state education department arranges the independent college to enroll the third batch of undergraduate students. The third batch of students have poorer cultural achievements in comparison with the first and second batches of students, with the reform of the education system, the third batch of undergraduate courses has been merged with the second batch, collectively referred to as the second batch of undergraduate [6]. This directly affects the improvement of the quality of education and teaching in independent colleges, and brings certain resistance to the quality construction of independent colleges.

\section{4) Method - School Software}

The school's software includes the teacher's teaching level, professional settings, professional curriculum settings, student learning resources and school management level. The teaching level of teachers is the core to ensure the quality of education. The situation of the teachers in independent colleges is described above and will not be repeated here. The problem with major settings is a general problem with all independent colleges. The major settings of the independent colleges are basically not set according to the orientation of the applied 
universities of the independent colleges. The basics are consistent with the major settings of the alma mater. What kind of major independent colleges are offered by the alma mater, no innovation. Not only the major is established with the same of alma mater, but also the setting of each professional course, the syllabus and the teaching materials are also adopted by the alma mater's teaching mode, which does not reflect the independent college's application-oriented teaching philosophy. The independent college students have relatively limited learning resources. The school library does not have enough books and online digital resources. The academic lectures held by the school are almost zero, which can not broaden the students' horizons. The management level of independent colleges also largely determines the development of the college. Many of the current independent colleges have not been separated from their alma mater, and the management is more chaotic, which is not conducive to the long-term development of independent colleges.

\section{5) Measurement - The Criteria of Assessment of Students}

Enterprises are judged by the test to determine whether the product is qualified. Now the basic school judges whether the student's academic qualification is qualified or not, and the test is the way for judging. This method of examination has existed in China for thousands of years. Nowadays, the enrollment and graduation of colleges and universities are adopted in this way. The independent college is positioned to cultivate applied talents for the country, emphasizing the combination of basic hands-on skills and cultural knowledge. The assessment criteria of an independent college cannot be copied from the alma mater's assessment method. According to the actual situation of the college to make reasonable assessment standards, independent colleges have a long way to go in this regard.

\section{6) Environment - Campus Culture}

Campus culture is formed through the long-term development of the school, just like the traditional Chinese culture. The campus culture is composed of many factors such as the school's living atmosphere and learning atmosphere [7]. A good campus culture is the basic guarantee for students studying at school. Due to the short development time of independent colleges, many independent colleges do not form a stable campus culture or the campus culture is very poor.

Through the above analysis, the quality of education is closely related to these six elements. One aspect fluctuates and the quality of education will fluctuate. The prerequisite for ensuring a stable output of the entire mass is to ensure the stability of these six elements. The overall quality of the products of the independent colleges is now poor. Although this is a kind of stability, it is not welcomed by the customers. Stabilization in the case of ensuring high quality output is a healthy state.

\section{INDEPENDENT COLLEGE EDUCATION QUALITY CONTROL}

The independent college wants long-term healthy development, and the first problem to be solved is the issue of the quality of education construction. The quality of education must be recognized by the society. The following describes the methods to improve the quality of independent college education from three aspects: input quality control, process quality control and output quality control.

\section{A. Input Quality Control}

As mentioned above, the source of students in Chinese universities is divided according to the results of the college entrance examination. In the college entrance examination enrollment policy, the enrollment batch of the independent college is arranged in the third batch of undergraduate courses. The independent college is also enrolling students nationwide. It is also the third batch of candidates in the undergraduate course. The quality of students in each province is also uneven. The quality of the students in the education province is relatively good, which is inseparable from the current state of education quality of independent colleges. Since the national policy cannot be changed, the only change that can be made is the independent college itself, improving the quality of its own education and thus improving the level of running a school. At present, most provinces in the country have already carried out the reform of the admissions batch. In 2015, Sichuan, Guangxi, Zhejiang and other places will merge second or third batches [8]. The original third-grade colleges and the original secondgrade colleges have enrolled in one batch, and the quality of the independent colleges is gradually improving. Some of the outstanding independent colleges have entered the first batch of undergraduate enrollment. For example, the auditing major of Jincheng College of Sichuan University has already enrolled in the first batch of undergraduate courses [9]. This shows that the input quality of independent colleges is significantly improved.

\section{B. Process Quality Control}

The undergraduate students of independent colleges and the undergraduates of ordinary higher education institutions are basically four or five years of schooling. The quality of education of independent colleges can be reflected throughout the training process. It will be stated in several points to control the quality of independent college education.

Optimize the teacher structure. As the second major subject of the school, teachers play an important role. The faculty structure of independent colleges is now a major challenge for all independent colleges. To this end, independent colleges should do a good job in the introduction of teachers, promotion of titles, and the amount of teachers. In addition, we must strengthen the cultivation of applied teachers and the ladder construction of full-time teachers. 


\section{SUMMARY}

Featured major settings. The major settings of independent colleges cannot be blindly consistent with the major settings of the alma mater. The major settings of independent colleges should be oriented to the needs of society and the market. Through research, to understand the application talents that are urgently needed in the society, set up some special majors. In terms of the setting of professional courses, it is also necessary to combine social needs with some courses that are closely related to actual needs.

The scale of running a school. In the case of all colleges and universities expanding enrollment, the enrollment scale of independent colleges is also increasing year by year. In the case of increasing enrollment, the hardware and software facilities provided by the school have not increased. This has resulted in only an increase in "quantity" and no improvement in "quality". Therefore, if the quality of education in an independent college is to be improved, it must control its enrollment scale and be less and more refined.

Increase funding input. Insufficient funding for independent colleges is a serious problem. This requires finding a way out through an independent college that combines its own situation. Strengthen the construction of school hardware facilities with sufficient funding.

Strengthen the guidance of students. As the main body of the school, the students are all working together. It is not enough to rely solely on the unilateral efforts of the school. In the process of training, students are guided to closely cooperate with the school's training mechanism to ensure that the training program is effectively implemented.

\section{Output Quality Control}

Graduates of independent colleges are relatively easy to compared with ordinary colleges and universities. The overall situation of graduates of independent colleges is poor material input and poor product output. It is necessary to strengthen the output quality control of independent college students. It cannot be used in the form of graduation design or graduation thesis like ordinary undergraduate colleges. Since the independent colleges train applied undergraduate graduates, independent colleges should develop conformity through research and discussion. The relevant standards for graduates of independent colleges reflect the characteristics of applied undergraduate graduates, innovative institutional mechanisms, such as the introduction of third-party evaluation mechanisms, more emphasis on students' hands-on ability, and the replacement of graduation thesis and graduation design with actual works. Secondly, it is necessary to control the graduation rate of graduates. Unqualified graduates must not graduate, thus improving the merit rate of graduates.
At present, the undergraduate education of independent colleges, as an important part of Chinese higher education, bears important social responsibilities. Today, with quality in school, strengthening the quality of education in independent colleges is a top priority for independent colleges. The quality of education in independent colleges is not only the responsibility of educators, but also the responsibility of the whole society. This paper discusses the whole process of education quality from the perspective of product quality. Through the three dimensions of input quality, process quality and output quality, this paper clearly points out the method of controlling education quality, which provides a reference for the development of independent colleges in China.

\section{REFERENCES}

[1] http://old.moe.gov.cn//publicfiles/business/htmlfiles/moe/moe_637/2004 08/1308.html.

[2] http://www.gov.cn/flfg/2008-03/07/content_912242.htm.

[3] http://www.gaosan.com/gaokao/150460.html.

[4] http://old.moe.gov.cn//publicfiles/business/htmlfiles/moe/s181/201305/1 52365.html.

[5] http://gaokao.eol.cn/zsxx_5425/20110616/t20110616_634926.shtml.

[6] http://www.cqzk.com.cn/news/html/2018/0606/32059.htm.

[7] Hou Changlin. Theoretical Research on Campus Culture in Colleges and Universities[J]. China Higher Education, 2013(23): 23-25.(In Chinese)

[8] Tang Liu, Gao Guoqiang. The Influence of the Entrance Examination Reform of College Entrance Examination on the Development of Colleges and Universities [J]. Industry and Technology Forum, 2018, 17 (01): 116-117. (In Chinese)

[9] http://zs.scujcc.cn/lnsj/07/6276.html. 